\title{
Virgilian Hauntings in the Later Poetry of Seamus Heaney
}

\author{
Ian Hickey \\ Mary Immaculate College, Limerick, Ireland
}

Copyright (c) 2018 by Ian Hickey. This text may be archived and redistributed both in electronic form and in hard copy, provided that the author and journal are properly cited and no fee is charged for access.

\begin{abstract}
This article examines the influence of Virgil upon the poetry of Seamus Heaney through the theoretical lens of Jacques Derrida's Specters of Marx. The paper argues that the present and future are influenced by spectres of the past through what Derrida would term hauntology. Heaney's later poetry inherits deeply from what has come before it in terms of classical mythology. Similarities are drawn between contemporary Northern Ireland and that of the classical past in the poetry and it is the circular, repetitive nature of history that enables the poet to locate a plateau, outside his primary world, to view the events of his present world.
\end{abstract}

Key Words. Seamus Heaney, hauntology, Virgil, history, circles.

Resumen. El presente artículo tiene como objetivo estudiar la influencia de Virgilio en la poesía de Seamus Heaney. Se seguirá para tal fin el enfoque proporcionado por Jacques Derrida en su libro Specters of Marx. Se parte de la base de que el presente y el futuro están influidos por espectros del pasado, por medio de lo que Derrida denomina espectrología (hauntology). La poesía tardía de Heaney ciertamente hunde sus raíces en la tradición anterior, especialmente en lo referido a mitología clásica. En una serie de similitudes entre la Irlanda del Norte contemporánea y la antiguiedad, en este trabajo se indica que es la naturaleza circular y repetitiva de la historia lo que permite al poeta situarse en un plano alejado de su mundo más cercano y desde ahí considerar los acontecimientos del presente.

Palabras clave. Seamus Heaney, espectrología, Virgilio, historia, círculos.

Many Irish poets have been quick to adopt classical mythology into their work because it adds a sense of universality to their primary worlds. Richard Kearney notes that Seamus Heaney is similar to Kinsella, Montague and Durcan in that all have "succeeded in rediscovering home away from home, in rereading their native myths and memories from an alternative place foreign, uncharted, unhomely, unheimlich" (43). In doing so, poets are enabled to view their society from a different viewpoint. This article will focus on the poetry of Seamus Heaney with specific emphasis being placed on the influence that Virgil had on his works. Jacques Derrida's idea of hauntology will be used as a lens through which to view this influence, and also to show that history repeats itself through the guise of what he terms the spectre. In 
Specters of Marx Derrida notes that "the spectre is the future, it is always to come, it presents itself only as that which could come or come back" (48). Much of Heaney's later poetry borrows from certain aspects of Virgil's works to add a sense of universality to the Northern Irish experience. The Irish poet draws carefully chosen parallels between his world and that of Virgil's to show that the actions and ideas of the past can be linked with the present and future. Derrida notes that each text has an original text from which it is created and that the act of writing itself is merely recreating or repeating that which has already happened:

repetition does not reissue the book but describes its origin from the vantage of a writing which does not yet belong to it, or no longer belongs to it, a writing which feigns, by repeating the book, inclusion in the book. Far from letting itself be oppressed or enveloped within the volume, this repetition is the first writing. The writing of the origin, the writing that retraces the origin, tracking down the signs of its disappearance, the lost writing of the origin (Writing and Difference 372).

The recreation of older, original texts is something that has been done for centuries in Ireland. At the beginning of the twelfth century, according to Declan Kiberd, "the first Irish language translation of Virgil, Imtheachta Aeniasa, made its appearance: and therefore texts abounded with comparisons between local heroes and Aeneas, local beauties and Helen, local scholars and Ennius" (vii). Thus, Heaney choosing to incorporate Virgilian myth into his poetry is not unique but something that has been repeated throughout Irish literary history. This article will examine three poems from the later poetry of Heaney: "Bann Valley Eclogue", "Virgil: Eclogue IX" and "The Riverbank Field". It will be shown that the present and future is inherited from the past through the workings of the Derridean spectre.

Many similarities can be drawn between the personal and private lives of both Heaney and Virgil, but these connections also hold true in a poetic sense. Virgil was born into a peasant family in the countryside in the Andes area near Mantua where he lived for much of his childhood. Much of his early life revolved around the pastoral and the rural. His early poetry reflects his childhood memories and has deep agricultural images within it. In a manner which anticipates Heaney's early modus operandi Virgil wrote about what surrounded him in the countryside. In Preoccupations Heaney discusses the definition of the "pastoral" noting that:

"Pastoral" is a term that has been extended by usage until its original meaning has been largely eroded. For example, I have occasionally talked of the countryside where we live in Wicklow as being pastoral rather than rural, trying to impose notions of a beautified landscape on the word, in order to keep "rural" for the unselfconscious face of raggle-taggle farmland ... Originally, of course, the word means "of or pertaining to shepherds or their occupation" and hence a poem, play, etc, in which the life of shepherds is portrayed, often in conventional manner: also extended to works dealing with country life generally. (173)

What is interesting about the chapter "In the Country of Convention", from which I have quoted above, is that Heaney makes the argument that Theocritus, Virgil, Horace, Mantuan and Marotthose should have been included in the anthology The Penguin Book of English Pastoral Verse. However, the most interesting part is that he calls the works of these writers "informing, influencing voices" (Preoccupations 175) which resonates with Derrida's idea of hauntology in that these non-present individuals have a presence in the present.

Jacques Derrida first presented his idea of hauntology in Specters of Marx. The etymology of the word itself can be traced to ontology, as in French phonology the words 
"ontology" and "hauntology" sound strikingly similar. Derrida discusses the idea of hauntology using the spectral figure of the ghost in Shakespeare's Hamlet. Like the ghost in Hamlet, the spectre leaves and returns bearing information from the past to influence and guide the present and future. However, for Derrida, the spectre is not a physical being, it has a non-present presence. The spectre cannot be seen but exists within, and haunts, the unconscious of the individual with Derrida noting that 'to be...means, for the same reason, to inherit' (Specters 67). One inherits ideas from these spectres and is moulded by them. Derrida also adopts the idea of a multitude of spectral figures from Karl Marx. In his text, Derrida quotes Marx: "'One hears," Marx quotes, "millions of spirits speak through the mouths of people" (169). Marx has a haunting influence over a text first published in French in 1993 with his spectral voice speaking through Derrida. It is this which Derrida establishes as the workings of the "spectre". The predominant idea within the text is that Marxism still exists beneath the surface, in the unconscious, and can resurface at any time. It never dies but instead can resurrect itself when it chooses and haunt the present. Derrida notes that "a spectre is always a revenant. One cannot control its comings and goings because it begins by coming back" (Specters 11). The non-present presence of the spectre is not only limited to Marxism but is open to any idea, line of thought or practice that has happened in the past. Existence is a trace of hauntings and literary texts are no different. In post-structuralist theory, then, the poet is seen not as in control of language, but rather as being implicated in the socio-linguistic contract that pre-dates, and is a seminal factor in, the subjectivity of the poet. Richard Harland draws the following conclusions:

The individual absorbs language before he [sic] can think for himself: indeed, the absorption of language is the very condition of being able to think for himself. ... Words and meanings have been deposited in the individual's brain below the level of conscious ownership and mastery. They lie within him like an undigested piece of society. (12-13)

In practical terms, this means that Heaney's work is not only rooted in, and influenced by, Irish history and culture, but is haunted and inhabited by spectral presences of other cultures and texts.

From both a pastoral and political perspective, Heaney's unconscious has been influenced by these spectres. Virgil, like Heaney's Northern Ireland, lived in a period of civil unrest and in a time where sectarian violence was predominant throughout much of Italy. In terms of political engagement Virgil's Aeneid succeeds in working within the framework of its time. It replicates and borrows from Homer's epics, the Iliad and the Odyssey, to present a strand of poetry that borrows from what has gone before it. Philip Hardie notes that the text itself is "a place where the laws of time in the historical world are suspended, and where the epic allows the hero and reader to range into the past and future" (21). In this sense, it is a rather hauntological text. It is haunted by the civil unrest that occurred in Italy between Marius and Sulla, which was soon followed by the wars between Pompey and Julius Caesar for ultimate control and power over Rome. It must also be noted that Virgil's Aeneid is considered to be supportive of Empire and can be linked in Irish terms with the British Empire. However, both poets differ is in their presentations of political allegiances. Heaney remains true to his Irish identity, that formed by cultural hybridity, and does not support notions of Empire in his works. Heaney operates on the basis of not forgetting the past, but overcoming it to create a society of acceptance and inclusivity of the Other. In his interview with Dennis O'Driscoll he discusses the right of Protestant neighbours to celebrate their history: "I remember going out to the end of the lane at Mossbawn to watch an Orange band march and to wave at people we knew - including Alan and George Evans dressed up in their 
sashes. There was no problem at that personal level: if you were friends with the people you conceded their right to their affiliations" (Stepping Stones 133).

Where Heaney's quarrel lies is with the brutal, futile sectarian killings that were carried out by paramilitaries. Virgil uses the Aeneid to propagate propagandist ideologies of nation, state and Empire. His text was "conceived and shaped as a national and patriotic epic for the Romans of his day" (Williams 37), while Heaney merely attempts to locate a space where a more open understanding of the violence that has unfolded in his native land can be found. Hardie broadly agrees with Williams's line of thought. He notes that the Aeneid "plays a major part in the invention of the European myth of Empire" (93). Heaney consciously does not adopt the same line as Virgil in this regard. For Heaney, the classics are a way of locating himself in the wider European world and for understanding his own society from this perspective. To engage with these classics is to be haunted by the spectres that dwell within them but does not mean that personal values have to be disregarded. Heaney notes in Stepping Stones that:

\begin{abstract}
When I say "canon", I'm thinking Homer, Virgil, Dante, Shakespeare ... These are nuclear deterrent words almost! But they can be reread in terms of new idioms. Which is to say they are classics, secure because of their human and foundational quality. Another voice will cry out that that's a Eurocentric attitude to things. It certainly is - that's where they come from and where I live and it's part of my equipment for locating myself in time and consciousness. You don't have to abandon values which you have created yourself in order to be open in the world to other values. (456)
\end{abstract}

Heaney constantly revisits motifs from his earlier poetry in the later texts. During the Troubles, he chose Nordic and Viking mythologies as a lens through which to understand the violence that was happening in its contemporary context. Similarly, in the later poetry from Seeing Things to Human Chain Heaney repeats this practice through adopting certain elements of Virgilian and Dantean myth into the poetry. The haunting nature of the past plays a key role in Heaney being lured to Virgil as a poetic spectre and allows for chosen aspects of thematic continuity to be traced through the poetry of these two very different writers.

Heaney immediately invokes the spirit of Virgil in "Bann Valley Eclogue" by using the original Latin of Virgil's text as an epigraph, "Sicelides Musae, paulo maiora canamus", "(Sicilian Muses, let us sing a somewhat loftier strain)" (Electric Light 11). Michael C. J Putman notes that "this serves to bring into the poem the great Latin master himself" (12). There is then a shift towards a more Irish version of this line, while the spectre of Virgil hovers in the background. The reader is transported to contemporary times by Heaney appealing to his own, local "Bann Valley Muses, give us a song worth singing" (Electric Light 11). One presumes that the "Poet" of the text is Heaney, and this immediately conjures thoughts of his own personal, Irish past. The religious connotations such as "And it came to pass", and "In the beginning" (11), add to the Virgilian undertones within the text, and hark back to the past. These signs of the past signal the inheritance at play because "as soon as a sign emerges, it begins by repeating itself" (Derrida, Writing and Difference 374). The initial use of possessive language in "help me" and "my hedge-schoolmaster Virgil" (Heaney, Electric Light 11) suggests that the beginning of Heaney's mythical musings began not in Sicily, but in the local classroom of Northern Ireland, where he was first exposed to such literary fortitude by Father Michael McGlinchy:

I was lucky too in the teacher I had during my senior years: Father Michael McGlinchey, who loved the language and had a feel for the literary qualities of the 
texts especially Virgil. One of our set books was Book Nine of the Aeneid, but I always remember him repeating at different times, 'Och, boys, I wish it were Book Six' - which gave me an interest in that book long before I ever read it. (Heaney, Stepping Stones 295)

This is the point in time where Heaney was exposed to the spectre of Virgil, however, it ruminated in his unconscious for many years before this spectre of the past would come to the surface in his writing. Heaney seems to recognize certain elements of his own life and experiences in Virgil's Eclogues:

Here was a young poet coming back with an almost vindictive artistry against the actual conditions of the times. There was something recognizable at work, a kind of Muldoonish resistance. Virgil's eclogues proved an effective way for a poet to answer whatever the world was hurling at him, so I had a go at writing a couple of my own. (Stepping Stones 389)

It is worthy to note at this point that it is the Italian poet's moments of outcry against the harshness of life, the civil war and continuous violence that Heaney admires and places in his poetry, and not the propagandist, Empire spreading stance Virgil would ultimately take. Heaney connects with the past poet's desire to address the world around him, and the violence within it. The child of the first stanza can be looked upon in both a literal and metaphorical manner. One can assimilate it to the real child who was to come into the world, a niece; or it could be interpreted as the personal, almost familial attachment that the poet feels to his work. The poem is the offspring of his imagination, and by extension, of the spectre. In this sense when Meg Tyler discusses the poetry of both Heaney and Longley, she cleverly asserts that by utilising classical myth it "has the effect of extending their literary domains" (17), while at the same time making the otherworldly home. The final line of the first stanza brings about the old spectre of colonialism and civil war when Heaney notes that "Maybe, heavens, sing Better times for her and her generation" (Electric Light 11). The first section ultimately sets up what is to be engaged with in the rest of the poem.

While the pastoral element that "Bann Valley Eclogue" upholds allows the poet to negotiate freely around rural and wider societal issues, Iain Twiddy contends that the pastoral within Heaney's poetry amounts to a way of dealing with the continuous passing of time: "The eclogue in particular is concerned with things passing, whether lost love, the changing seasons, or dispossession and the loss or alteration of nature itself. In addition, the eclogue, and especially one of its forms, the pastoral elegy, show that things can be given up and that it is possible to be reconciled to substitutes" (126).

I would argue that this is true. Heaney deals with the passing of time by making it repeat itself through blending the past, mythical writings of Virgil into his poetry. The mythical spectres of the Aeneid are transitional figures in the poem. Virgil, in an act of prosopopoeia, is in dialogue with Heaney, and lays out commands for the poet: "Carmen, ordo, nascitur, saeculum, gens" (Heaney, Electric Light 11). Heaney himself delivers his own translation of these commands as part of the poetic process. In translating the Latin to English Heaney is unifying both worlds together through the limitlessness of language:

Their gist in your tongue and province should be clear

Even at this stage. Poetry, order, the times,

The nation, wrong and renewal, then an infant birth

And a flooding away of all the old miasma. (Electric Light 11) 
Justin Quinn discusses Heaney's use of these foreign cognates when he notes that: "He frequently carries out this imaginative work by introducing foreign phonemes, as they seem to promise even stronger geographies, cultures and mindsets, that challenge his own considerable powers of domestication" (48). The use of Latin and allusions to links between Roman and contemporary times enables Heaney to trace a commonality between both worlds and embodies Geoffrey Bennington's notion that "the trace is the origin of the origin" (21). This implies a continuous binding and haunting of the past and present in literature. The Troubles are compared in the poem to the fratricide of Roman times, when Romulus killed his brother Remus. Such acts of violence and barbarity have repeated themselves throughout history with Heaney's poetry referring to Nordic, Roman, Greek and Irish instances of such violence. In the poem Heaney's request to "give us a song worth singing" (Electric Light 11) suggests a hope that the future will be a new dawn of peace and unity:

But when the waters break

Bann's stream will overflow, the old markings

Will avail no more to keep east bank from west.

The valley will be washed like the new baby. (Electric Light 11)

Like the Heaney of "Station Island", he asks for advice on the new world that is to come. The new peace that is hoped for rests in the hands of the new child, which is almost Christ-like in a metaphorical sense. In "Station Island V", Heaney asked the ghost of his teacher for advice:

As I stood among their whispers and bare feet

the mist of all the mornings I set out

for Latin classes with him, face to face,

refreshed me. Mensa, mensa, mensam

sang in the air like a busy whetstone. (Station Island 73)

This passage, although highly spectral in its own right, is deeply connected with "Bann Valley Eclogue". The image of the teacher, presumably McGlinchey, also Heaney's gateway to Virgil, is extremely haunting given that the poet already refers to Virgil as his teacher in the opening stanza of the poem. Just as Heaney asked his teacher for advice, he now asks Virgil for advice. The spectres' non present presence has come to the fore in this regard:

Pacatum orbem: your words are too much nearly.

Even "orb" by itself. What on earth could match it? (Electric Light 12)

The thoughts of both poets are linked through the spectre of the past. Heaney inherits the same line of thought as Virgil in the dialogue; "Pactum orbem" translates to a world made peaceful. The line "Let her never hear close gunfire or explosions" (Electric Light 12) harks back to past violence and is a reference to the contemporary violence that unfolded during the Troubles but ties the hope of a peaceful future within it.

While the repetitive thoughts and actions of both worlds collide in the poem, the new life and hope that is the child is to be welcomed. The child also acts as a symbol of the past that is always to come, to repeat itself. The final stanza of the poem is littered with images of roundness and circularity:

Child on the way, it won't be long until

You land among us. Your mother's showing signs,

Out for her sunset walk among big round bales. 
Planet earth like a teething ring suspended

Hangs by its world-chain. Your pram waits in the corner.

Cows are let out. They're sluicing the milk-house floor. (Electric Light 12)

The sunset, bales, planet earth, teething ring, world-chain and pregnant belly all imply the circularity and continuation of life. The round sun of the past and present will set to bring a new day and age of hope. The rural, pastoral element of life is connected with the round bales of the section, but it is also interesting to note that it is the pregnant woman who walks among the bales. This suggests that nature and the local is what will hold strong amongst the wider world of planet earth and that notions of politics and ideology are not overtly important. However that being said, all are linked in the "world-chain" of life and community, just as the poet is linked with the classical world of literature through the presence of the spectre. What "Bann Valley Eclogue" accomplishes is to suggest that the continuing passage of time is not linear but repetitive. Time essentially has no bounds given that the spectre transcends time and dooms history and human nature to repeat itself regardless of culture or tradition. The violence that Virgil witnessed during his lifetime finds a corresponding framework amongst the Northern Irish situation.

Electric Light is a collection that pays homage to the master poet Virgil. The translation of Virgil's ninth eclogue, "Virgil: Eclogue IX", demands a literal reading of the discussion that takes place between the two farmers, Lycidas and Moeris, and for this discussion to be placed in an ostensibly Irish context. The poem is deeply intertextual and is effectively controlled by a variety of spectres, some Roman, some colonial, but the majority Irish. Sung-Hee Yoon states when discussing intertextuality that "any text is the absorption and transformation of another" (69). "Virgil: Eclogue IX" conjures spectres of colonialism, and voices the predicament more loudly than "Bann Valley Eclogue". The latter deals with community and fellowship in post-Troubles Northern Ireland, whereas the former harks back to the eternal colonial spectre that haunts Heaney's psyche. In "Dialangues" the process of writing and its influences are discussed by Derrida. He notes that writing is in itself a voicing of the spectre of the past that haunts the present and future:

When the voice trembles, when one hears that voice, one hears a non-localizable voice; it makes itself heard because its place of emission is not fixed. In an elliptical manner, I would say that, when a voice has its localizable place in a social field, it is no longer heard; when one does hear it, it is the voice of a ghost. (135)

Derrida's notion of the voice does not only apply to the spoken word, but also to the process of writing. The voice that one hears echo throughout the poem is that of Virgil and the classical past. However, as I have discussed earlier in this article, Derrida addresses the concept that a multitude of spectres haunt the unconscious and therefore a variety of voices from the past influence the present. The poem incorporates spectres of both Italian and Irish descent and fuses them together. Heaney addresses the implications that colonialism has upon the common, everyday citizen, in this case the farmer. He attends to this from the middle ground. In a postcolonial sense the poet sees himself as being influenced and guided by the hybrid nature of his identity, Irish and British. In "Terminus" he writes of the in-between nature of his identity from an Irish historical perspective:

Two buckets were easier carried than one.

I grew up in between (The Haw Lantern 5) 
In "Virgil: Eclogue IX", the spectral presence of the Roman poet allows Heaney to view his own world through the lens of mythology. It also adds a sense of universality between the classical world and Northern Ireland. He now has a vantage point from where to discuss the commonalities between the classical world and his own. Donna L. Potts sees the poem as "a translation of rather than a tribute to Virgil" (71) given that Heaney translates and transforms the poem into one that is haunted by a variety of both Italian and Irish spectres. A wider spectrum of colonial hauntings are embraced by the poet as Eugene O'Brien notes in Seamus Heaney and the Place of Writing: "The presence of these figures symbolises the increasing breadth of Heaney's intellectual development, and also stresses that sense of kinship which he feels with voices from the classical past" (100). These voices from the classical past, as O'Brien terms them, are haunting and intertextual. Virgil's world of civil war is linked with issues that surround contemporary Northern Ireland and its past:

The last thing

You could've imagined happening has happened.

An outsider lands and says he has the rights

To our bit of ground. (Heaney, Electric Light 31)

This statement by Moeris in the poem reflects the imperial reward that was given to soldiers at the time. Land was removed from the possession of the local, ordinary people, and given to these soldiers as a reward for their efforts during Virgil's time. During the plantations of Ireland the same method of reward was given to British soldiers and this further emphasises the link between both poets' worlds. The spectre of W. B. Yeats in the two words "All's changed" (Heaney, Electric Light 31), a haunting reference from Yeats's "Easter 1916", suggests that on the surface the physical world will now undergo a series of changes due to the possibility of violence yet beneath the surface the haunting, repetitious nature of colonialism played out in Virgil's text repeats itself in an Irish context during Heaney's life. In Points, Derrida notes that "I love repetition, as if the future were entrusted to us, as if it were waiting for us in the cipher of a very ancient speech - one which has not yet been allowed to speak" (130). This is the very locus of the function of hauntology played out on a field of constant inheritance throughout history and the future. While one is accustomed to imagery in the poetry that reflects the rural, hearty landscape of the Ireland of turf, flowing rivers and wild mountains, the "old scraggy beech trees" (Heaney, Electric Light 31) symbolically reflect the withering nature that Empire has upon the common individual and wider society. Iain Twiddy attains a true sense of the poem when he notes that:

In Electric Light, Heaney's translation of Virgil's ninth eclogue concerns the difficulty of healing the wounds inflicted by civil war. It concentrates on the use of the eclogue as the site of political complaint, and reflects the tradition of pastoral lament in Ireland. (126)

Heaney's use of the eclogue allows the poet to address the issue of violence and Empire in Ireland through the guise of Virgilian myth.

In the poem, Menalcas is the one that holds out amongst the forces of violence and imperialism that surround him. Song, an element of pastoral poetry, is his way of dealing with, and addressing, the events of his time. Menalcas is representative of both Virgil and Heaney's thoughts on how to deal with the violence in their lands through an aesthetic prism. However, the truism that a song or poem can never stop a bullet rings true within the text, and is voiced by the man on the frontline, Moeris: 
But songs and tunes

Can no more hold out against brute force than doves

When eagles swoop. (Heaney, Electric Light 31)

The eagle within the poem is a symbol of the Roman Empire, which spread Latin, Roman culture and Christianity throughout Europe. Languages and peoples were invaded in the time of Virgil's writings, just as Ireland was by the Vikings and later by the British. Heaney is tying the past with the present in this regard. Music and song, which litter the poem, can be expressed in Irish terms as the loss of language, Gaelic:

Shocking times. Our very music, our one consolation, Confiscated, all but. And Menalcas himself

Nearly one of the missing. (Electric Light 32)

Again language is to the fore of the postcolonial discussion in the poetry, and unsurprisingly Heaney, as he always has done, locates a place between both worlds to view both on equal terms. This is done through the employment of classical mythology which exhumes a commonality between the past and present. Heaney is not forceful in his approach, but instead points to the subtle, yet major, hauntings between Virgil's world and his own, thus removing any sense of him taking sides or overtly discussing the colonial spectres of his own countries past, present and future. By mingling carefully chosen aspects of Virgil's works into his own poetry Heaney is pointing to the presence of elements of the past that can be recognized in contemporary Northern Ireland.

The poet himself notes the unity between both worlds in his article, "Eclogues 'In Extremis': On the Staying Power of the Pastoral", albeit subtly, and in a manner that allows the reader to invoke their own interpretations of historical instances:

The muses of Sicily who inspired the earlier poet's idylls are always at the back of the Latin poet's mind. Virgil, to put it another way, is himself very much the learned poets' poet; he may have come from a country background but he has an eye on an audience very different from the shepherds and goatherds he would have known in his boyhood, on the farm from which his father was eventually expelled. (3)

This is precisely the experience of Heaney's poetics. The farmer's son who came to speak and write for and to the Irish nation, along with the wider world, now has a very different audience to that of his early years. This is where the personal side of Heaney comes to the fore in this eclogue, just as it did in "Bann Valley Eclogue" before it. The uncertainty of writing and finding his way in the poetic world still exists for a man who has honed his craft to perfection over a period of forty years, and can almost be linked back to his earlier pen name "Incertus", the Latin for "uncertain", when he first started writing:

The Pierian muses

Made me a poet too, I too have songs,

And people in the country call me bard,

But I'm not sure: I have done nothing yet

That Varius or Cinna would take note of.

I'm a squawking goose among sweet-throated swans. (Heaney, Electric Light 32)

The uncertainty of Lycidas mirrors the uncertainty of Heaney with regards to his own writing; he was "Uncertain. A shy soul fretting and all that" (Opened Ground 91) in the beginning. 
While the personal laments of the poet ring through in the poem, the predominant discourse revolves around the colonial. An inherently Irish spectre resounds throughout the text. Derrida discusses the notion that once the book is written it takes on a life of its own. A text is never finished because of the multitude of spectres that reside within it and give it constant renewal: "Between the too warm flesh of the literal event and the cold skin of the concept runs meaning. This is how it enters into the book. Everything enters into, transpires in the book. This is why the book is never finite. It always remains suffering and vigilant" (Writing and Difference 92). Regarding Heaney's poetry, it is impossible to remove the spectres that haunt the text. Singularly, the spectre does not create a context but through the limitlessness of the position it holds demands that a variety spectres unite to create one with David Appelbaum noting:

Improperly without proper place, the spectre is absolutely dispossessed of site, an unfixed point definitely in the world. A strange birth: the possibility of the spectre exudes from the interstices of phenomenology itself. The apparition of the apparition is the sine qua non of the transcendental reduction. (30)

The overpowering nature of colonialism collides with the world of resistance in the poem. Menalcas "will keep singing and keep the songs" (Heaney, Electric Light 34), but he is merely one of the very few concerned with this practice; he is like Virgil and Heaney in this regard. Heaney sees his role in society and the Troubles' paralleling that of Menalcas. Lycidas and Moeris represent the common man who seeks to use what they have in the world and carry on regardless of the circumstances. Despite the terrible grievances that have befallen the men at the beginning of the poem, they are willing to carry on and move forward with their lives:

That's enough of that, young fellow. We've a job to do

When the real singer comes, we'll sing in earnest. (Electric Light 34)

By using Moeris in the closing lines Heaney asserts that the common citizen must move forward in the face of violence. Heaney is suggesting using and overcoming the past to create a future free from sectarian violence and murder.

"The Riverbank Field" is a strikingly haunting poem. It incorporates Heaney's attitude towards myth and its usage within the realm of the local Irish landscape. Human Chain sees the poet rework and reimagine all that has been written before this collection. It is a collection of ghosts, both literary and personal, with Heaney commenting on myth that "those modes are forever available and I'd hate to cut myself off from them" (Stepping Stones 108). In the ghostly fashion in which "The Riverbank Field" has been born, the voices of the past resound within its lines. Like "Bann Valley Eclogue" and "Virgil: Eclogue IX" Heaney adopts his subject matter from Virgil, in this case Aeneid VI. Michael Parker notes that the poem is essentially the foundation of "Route 110" through its "multiple acts of translation - temporal, spatial, linguistic, intellectual, cultural, psychological, cultural, political" (156), and in this sense both poems haunt each other in the collection. Heaney reimagines Virgil's work and places it amongst an Irish setting. Walter Benjamin notes that "a translation comes later than the original, and since the important works of world literature never find their chosen translators at the time of their origin, their translation marks their stage of continued life" (254). This continuation of the life of a text adds to the renewal that Virgil's Aeneid undergoes in 'The Riverbank Field'. Irishness is deemed as important as classical poetry and mythology by Heaney: 
Ask me to translate what Loeb gives as

"In a retired vale ... a sequestered grove"

And I'll confound the Lethe in Moyola (Human Chain 46)

Not only does Heaney use James Loeb's translation to show the progression of translation as a process, he also determines the local Moyola River to be of equal importance to the mythical Lethe. The most important word in the poem is "confound" because to trace the etymology of the word opens up the heart and intention of the poem. "Confound" is a Middle English word, however, when traced back to old French, "confondre", and further back to Latin, "confundere", one finds its translation to mean "to pour together" or "to mix up". This is what Heaney achieves in this poem. "The Riverbank Field" is a mixing together of the Virgilian spectre that has haunted him throughout his life with his rural, local, Irish landscape. Robert Tracy acknowledges that the poet "confronts Virgil directly, merging the Roman poet's underworld into the South Derry landscape of his childhood, and finding there a kind of affirmation" (269). The scene is inherently Virgilian with an Irish twist:
Moths then on evening water
It would have to be, not bees in sunlight,
Midge veils instead of lily beds; but stet
To all the rest: the willow leaves
Elysian-silvered (Human Chain 46)

Heaney makes the setting his own. The poem is not a literal translation of Aeneid VI, but is an obscure inheritance where "the spectre is also, among other things, what one imagines, what one thinks one sees and which one projects - on an imaginary screen where there is nothing to see" (Derrida, Specters 125). The trace of the original text is present, Heaney does not discard it, but invokes a comparative that places Irishness on a par with the classical world in a wholly imaginative sense. Derrida notes that a book acts in a form of lending, of repetition. Virgil's images lend themselves to an Irish domain but "once it lends itself a single time to such a representation - that is to say, once it is written - when one can read a book in a book, an origin in the origin, a center in the center, it is the abyss, is the bottomlessness of infinite redoubling" (Writing and Difference 374). The poet's dealings with Virgil have been a constant redoubling and progression that have resulted in the creation of this poem. I would argue that Heaney purposely does not engage with the Empirical spectre that is often associated with Virgil's text, but instead traces the similarities between both the past and the present. Heaney notes in Stepping Stones that Latin and traces of language had always been used by him when speaking to his daughter:

For her education too, of course. When she started college I used to introduce crazy transliterations. If the gates came down unexpectedly at the level crossing in Sydney Parade, I'd cry out "Sanctos fumos!" or maybe "Sanctum Jesum!" and then exclaim, "Exclamatory accusative!" Sometimes I'd use the macaronic method, in Irish and Latin, to ask if she had the key to the house: "Eochar habesne?" Or even, to emphasize that accusative case, "Eocharum habesne?"... But that first introduction to the historical dimension of language readied me for something. It was an intimation of the different strains and registers that go to make up the whole keyboard. (296)

The two worlds collide in a cacophony of language and imagery that places the poet between worlds and cultures: that of the classical past and contemporary Northern Ireland. Heaney's 
primary world enforces the Irish dynamic within the poem and concludes that the world is made of "spirits" (Human Chain 46) from the past who exist in the present, or in Derridean terms, the spectre. The inclusion of place names such as "Back Park", "Grove Hill", "Long Rigs" and "Upper Broagh" again stresses the Irish element outwardly projected in the poem. However, the method and reasoning of their inclusion is Dantean and conjures ghostly hauntings from the Commedia. This adds another layer to the poem while also reinforcing the notion that it encompasses the entire catalogue of classical myth that has been a constant in Heaney's work especially the middle poetry. Interestingly it was Virgil who also guided Dante in The Divine Comedy just as Virgil's spectre guides Heaney in his writing. Where Dante resides, so too does violence and terror, or at least memories of it. The translation of "domos placidas, 'those peaceful homes" (Human Chain 46) again sees Heaney rekindling the issue of sectarian violence, in a manner similar to that of "The Strand at Lough Beg" or "Ugolino". It now exists beneath the surface of society in a more peaceful Northern Ireland. There is a specific correlation here between the disarming of the paramilitaries, at least on a grand scale, and the immobilizing of soldiers within Virgil's Aeneid. Michael R. Molino views the poem as offering:

an Irish variation on classical landscape ... and envisions a peaceful world of ordinary life that parallels the Elysian Fields where Aeneas witnesses former soldiers immobilize their weapons and release their war horses unharnessed to graze in green pastures, taking the joy now in peace that they once took in battle (105).

The poet references the need to demobilize armies in the public sphere, and draws comparisons between past and present issues. He has been influenced by literary traditions through inheriting from those before him, however, within "The Riverbank Field", the poet acknowledges that he has done so "In my own words"” (Human Chain 46).

The spectral influence of Virgil on Heaney's later poetry has been a predominant theme in the three poems discussed in this article. Circular images pervade the final two stanzas where Heaney acknowledges the "presences" who dwell in the underworld (Human Chain 46). The words "time's wheel" (46) and the "dome of the sky" (47) link to the circular and repetitive nature of the past and is similar to the imagery employed at the end of "Bann Valley Eclogue". This shows that inheritance and spectrality have been influential in creating the poetry. Derrida notes that the spectre is forever influential when he states that "a heritage is never natural, one may inherit more than once, in different places and at different times, one may choose to wait for the most appropriate time, which may be the most untimely - write about it according to different lineages, and sign this more than one import" (Specters 211). In essence, this is the locus of Heaney's poetry. He is a Northern Irish poet that has incorporated Irish and British notions of identity into his work along with wider European cultures such as Greek, Scandinavian and Italian. The mixing of these spectres culminate in the deeply haunting poetry he produces. In the context of "The Riverbank Field" one cannot ignore the presence of Virgil's Aeneid in the final two stanzas:

\footnotetext{
All these presences

Once they have rolled time's wheel a thousand years

Are summoned here to drink the river water

So that memories of this underworld are shed

And soul is longing to dwell in flesh and blood

Under the dome of the sky. (Human Chain 46-47)
} 
Once again, it is the sense of overcoming or shedding the shackles of the past that arises at the end of the poem, just as it did in "Virgil: Eclogue IX". By this time Heaney knew that he was in ill health after having suffered a stroke, therefore, the spectre of Virgil takes on a new role in Heaney's personal, Irish mythology. The concluding lines of "The Riverbank Field" look towards a new future. Those who resided in the underworld for a thousand years were granted new bodies in order to leave the underworld. Where Heaney once delved into the underworld in an attempt to meet the shade of his father in "The Golden Bough", he now sees his first world as his own eternal Elysium. Like Virgil before him Heaney has created works that will live on after he has physically passed from this world. The crossing over to the other side allows the poet to regain and carry on a new life like the act of translation allows his poetry to be reformed and influenced by spectres of the past. Heaney has used myth throughout his poetic career with the first usage coming in "Personal Helicon" from Death of a Naturalist. Now, in the later poetry, Heaney readies himself to enter the realm of myth and reside there for eternity.

\section{Works Cited}

Appelbaum, David. Jacques Derrida's Ghost: A Conjuration. New York: SUNY Press, 2009. Benjamin, Walter. "The Task of the Translator". Walter Benjamin: Selected Writings Volume 1. 1913-1926. Ed. Marcus Bullock and Michael W. Jennings. Massachusettes: The Belknap Press of Harvard University Press, 2002. 253-263.

Bennington, Geoffrey. Not Half No End: Militantly Melancholic Essays in Memory of Jacques Derrida. Edinburgh: Edinburgh University Press, 2010.

Derrida, Jacques. Deconstruction in a Nutshell: A Conversation with Jacques Derrida. Ed. John. D. Caputo. New York: Fordham University Press, 1997.

. "Dialangues". Points ... Interviews 1974-1994. Ed. Elisabeth Weber. Stanford: Stanford University Press, 1999. 132-155.

. Writing and Difference. Oxon: Routledge, 2001. Specters of Marx. Oxon: Routledge, 2006.

Hardie, Philip. The Last Trojan Hero: A Cultural History of Virgil's Aeneid. London: I.B Tauris \& Co. Ltd., 2014.

Harland, Richard. Superstructuralism. London: Methuen, 1987.

Heaney, Seamus. Preoccupations: Selected Prose 1968-1978. London: Faber \& Faber, 1980.

. Station Island. London: Faber \& Faber, 1984.

- The Haw Lantern. London: Faber \& Faber, 1987.

- Opened Ground: Poems 1966-1996. London: Faber \& Faber, 1998.

. Electric Light. London: Faber \& Faber, 2001.

"“Eclogues 'In Extremis': On the Staying Power of Pastoral". Proceedings of the Royal Irish Academy: Archaeology, Culture, History, Literature 103C. 1. (2003): 112.

- Human Chain. London: Faber \& Faber, 2010.

Heaney, Seamus and Dennis O'Driscoll. Stepping Stones: Interviews with Seamus Heaney. London: Faber \& Faber, 2009.

Kearney, Richard. "Myth and Modernity in Irish Poetry". Contemporary Irish Poetry: A Collection of Critical Essays. Ed. Elmer Andrews. London: MacMillan Press Ltd., 1992. 41-63.

Kiberd, Declan. "Introduction". Amid Our Troubles: Irish Versions of Greek Tragedy. Ed. Marianne McDonald. London: Methuen, 2002. vii-xiii. 
Lysaght, Seán. "Human Chain: Poems (Review)”. New Hibernia Review 15.1 (2011): 151154.

Molino, Michael R. “The Freed Speech of 'Equivocal Words': Seamus Heaney's Door into the Light". 'The Soul Exceeds its Circumstances': The Later Poetry of Seamus Heaney. Ed. Eugene O’ Brien. Indiana: University of Notre Dame Press, 2016. 89106.

O'Brien, Eugene. Seamus Heaney and the Place of Writing. Gainsville: University of Florida Press, 2002.

Parker, Michael. "'Renewed, Transfigured, in Another Pattern': Metaphor and Displacement in Seamus Heaney's Human Chain". 'The Soul Exceeds its Circumstances': The Later Poetry of Seamus Heaney. Ed. Eugene O'Brien. Indiana: University of Notre Dame Press, 2016. 151-172.

Potts, Donna. L. Contemporary Irish Poetry and the Pastoral Tradition Columbia: University of Missouri Press, 2012.

Putman, Michael C.J. "Vergil and Seamus Heaney". Vergilius 59. (2010): 3-16.

Quinn, Justin. "Regionalism, Globalisation and Seamus Heaney's Latin lift-off”. Journal of European Studies 46. 1. (2016): 37-50.

Tracy, Robert. "Reviwed Work: Human Chain by Seamus Heaney". Irish University Review 41. 2. (2011): 266-271.

Twiddy, Iain. Pastoral Elegy in Contemporary British and Irish Poetry. London: Bloomsbury Publishing, 2012.

Tyler, Meg. A Singing Contest: Conventions of Sound in the Poetry of Seamus Heaney. New York: Routledge, 2013.

Williams, R. Deryck. "The Aeneid". The Cambridge History of Classical Literature Volume 2 Part 3: The Age of Augustus. Ed. E.J Kenny and W.V. Clausen. Cambridge: Cambridge University Press, 1983. 37-73.

Yoon, Sung-Hee. The Question of the Beginning and the Ending of the So-Called History of David's Rise: A Methodological Reflection and its Implication. Berlin: Walter de Gruyter GmbH \& Co KG, 2014.

Received: 10 October $2017 \quad$ Revised version accepted: 9 January 2018

Ian Hickey is a Ph.D research student under the supervision of Dr. Eugene O'Brien in Mary Immaculate College, Ireland. His current field placement is in Mary Immaculate College as a departmental assistant in the Department of English Language and Literature. He is interested in Seamus Heaney, Irish Poetry, Hauntology, Jacques Derrida and Literary Theory.

Ian.Hickey@mic.ul.ie 